\title{
破砕・石灰混合・締固めにより改良された 窯業副産物キラの骨格構造概念に基づく解釈
}

\author{
中野正樹 ${ }^{1} \cdot$ 山田英司 ${ }^{2}$ \\ 1 正会員 名古屋大学大学院教授 工学研究科社会基盤工学専攻（ $\bar{T} 464-8603$ 名古屋市千種区不老町） \\ E-mail: nakano@civil.nagoya-u.ac.jp \\ 2 正会員 名古屋大学大学院助教 工学研究科社会基盤工学専攻（ $\bar{T} 464-8603$ 名古屋市千種区不老町）
}

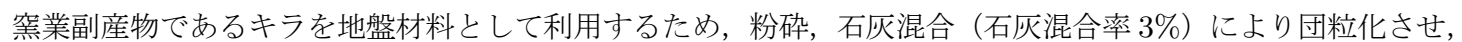
締固めたキラ改良土の力学挙動を, 室内試験および数值解析により解釈し, 以下の結論を得た。1) 未改良キラ の非排水せん断挙動は, 砂のそれに類似し, 骨格構造の働きに着目寸ると, せん断に伴う過圧密解消と構造劣 化の速度が同程度であると解釈できた．2) 仮置きなしでの改良土の一軸圧縮強度は，28 日養生により $500 \mathrm{kPa}$ まで上昇し，0 日養生の約 5 倍となった. また 28 日養生の一次元圧縮量も 0 日養生の $1 / 2$ 程度になった. 3 ) 仮 置きなしでの改良土の力学挙動を SYS Cam-clay model の構成式応答によって再現した結果, 破砕, 石灰混合, 締固めによって発展則パラメータが変化し, 構造劣化速度, 過圧密解消速度が遅くなった。 また養生により初 期構造が高位に，初期過圧密比が大きくなった。
\end{abstract}

Key Words : silt, lime, elasto-plasticity, SYS Cam-clay model, soil structure, overconsolidation,

\section{1. はじめに}

愛知県は日本最大の珪砂生産量を誇り, 平成 11 年の 旧通商産業局別の生産数量統計（(独）産業技術総合研 究所「日本の窯業原料データベース」）によると, 全国 生産量の約 $70 \%$ を占め, 中部地区では約 $80 \%$ にもな る. 珪砂から主にガラス製品, 鋳物型, 陶磁器などが 生産され,「瀬戸物」をはじめとする愛知県の地場産業 を支えている.

ところが珪砂精製過程や珪砂採取時には副産物とし て微粒珪砂，すなわちキラが大量に発生，その量は生 産量の $10 \sim 15 \%$ になり, 現在その大半は, 他に利用す ることができず1), 珪砂採掘場の跡地に埋立て処分して いる. 近年, 珪砂生産に伴い埋立て処分場の容量も逼 迫してきており, キラの処分問題は, 将来, 珪砂製造業 自体の危機, 地場産業の衰退を引き起こしかねず, 愛 知県, 中部地区の解決しなければならない課題となっ ている。

今までにキラをタイル原料, 瓦原料, 骨材等として 利用しているが，生産量が少なく，そのために高価に なり，それらの需要が珪砂製造業を支えるまでには至っ ていない。キラを大量に利用して, 安価で高品質であ る製品の作製が需要拡大には必要である.

そこで本研究は, キラを高品質な地盤材料・建設資材 に改変・創造することを目的とする．キラはもともと珪 砂鉱山から原材料を得ていて, 一般の土材料と同じ成分
を多く含んでいるため, 地盤材料としての利用の可能性 は高い. ところがキラは, 後述するようにシルト分が全 体の約 $70 \%$ を占め, また含水比 $33 \%$ 前後の脱水ケーキ として排出されるため, 強度は小さく, 振動により流動 化も起こしてしまう，そこで著者らは，チェーン回転式 破砕混合機2)を用いて, 脱水ケーキ状のキラをさらに細 かく砕き, 固化材として生石灰を混合することにより, 極めて均質な石灰混合団粒集合体を作って全体を締固 め可能な材料に改変し, それを締固めて新たな地盤材 料としてのキラ改良土を作製する. そして各種室内試験 を行うことによりキラとキラ改良土の力学挙動を把握 し, さらに土の骨格構造の働き（構造・過圧密・異方性） を記述する Super/subloading Yield surface Cam-clay model $^{3), 4)}$ (以下, SYS Cam-clay model と呼ぶ) を 用いてそれらのの力学挙動を再現する. キラ改良土が どのような強度をもち, どのように変形するのかとい う「性能」が評価され, 力学挙動を記述することによ り「品質保証」という付加価值が与えられれば, この 新地盤材料は, 格段に利用範囲が拡大寸る. 今回は特 に, 石灰混合による改良効果と養生による力学挙動へ の影響を, 骨格構造の概念に基づいて解釈する.

近年, さまざまな土に対するセメント系固化材を用 いた固化処理土の力学挙動把握の研究5) が進んでいる. 力学モデルの例として, 塑性ポテンシャルに Cam-clay 型を用い，セメントによる固結力を表すパラメータを 導入するもの $\left.{ }^{6)}, 7\right)$ ， モール・クーロン型破壊基準に損傷 
パラメータを導入するもの ${ }^{8)}$ ，軟岩に対す足立・岡のひ ずみ軟化型弾塑性構成式の概念を応用したもの ${ }^{9)}$ ながが 挙げられる.それぞれのモデルはセメントによる固化 作用を新たなパラメータにより表現している．本研究 では, 自然堆積土の力学挙動を説明する骨格構造の概 念に基づき，それを発展させている，すなわち固化作 用について, 骨格構造, すなわち構造, 過圧密, 異方 性の程度とその発展の仕方で表現している．本論文で は，キラの石灰による改良土の力学挙動を述べるが，本 論文でいう「改良土の力学挙動の弾塑性力学による記 述」はキラという特定の原材料に限定したものではな い. 今まで困難であったキラのようなシルト，そして石 灰改良土の力学挙動の再現, 解釈ができるならば，浚 渫土砂，特殊土や中間土などいわゆる「難処理土」とそ れらの固化処理土の力学挙動の記述に道を開くことが 出来る.これは新しい「地盤材料学」の端緒であって, 近い将来の地盤性能設計へ, 「地盤材料学」からの対応 にも大きく貢献できるかもしれない。

本論文の構成は, 2. において, キラの概要, そして 物性および力学特性を室内試験より求める. 必要に応 じて典型的な砂と粘土との比較を行う．3.では，破砕・ 石灰混合・締固めにより改良されたキラ（キラ改良土） の, 特に力学特性を, 室内試験を通じて求める. 4. で は, SYS Cam-clay model を用いた構成式応答との再 現から, 破砕・石灰混合・締固めによるキラの改良効果 を，骨格構造の働きに及ぼす影響として考察する.

\section{2. キラの物性および力学特性}

\section{（1） キラの概要と排出過程}

キラとは, 愛知県瀬戸地方における独特の呼び方で, ガラス製品の原料となる珪砂原土の精製過程において 大量に排出される微細な砂のことである ${ }^{1)}$. 珪砂の原料 は, 珪砂鉱山と長石鉱山より採取される. 愛知県瀬戸 周辺の鉱山を図-1 に示す.

図-2 に示寸珪砂精製過程より，キラが排出される工 程を説明する. 製品としての珪砂は, 珪砂原料を洗浄 することで, 粘土（水簸粘土）分を除去し, 粉砕, 分 級, 磁選, 脱水過程を経て得られる. また, 各工程で 使用した泥水は, シックナータンクにて微砂分や粘土 分を沈殿させ，高圧フィルタープレスにより， $700 \mathrm{kPa}$ 程度で 1 ～ 1.5 時間圧縮して水を搾り出し, 脱水ケーキ (写真-1) として排出される.この微粒珪砂がキラであ る. 高圧圧縮プレス過程を経ているため, キラの排出 時の含水比は $33 \%$ 前後で一定となっている (以後, 脱 水ケーキキラと呼ぶ).

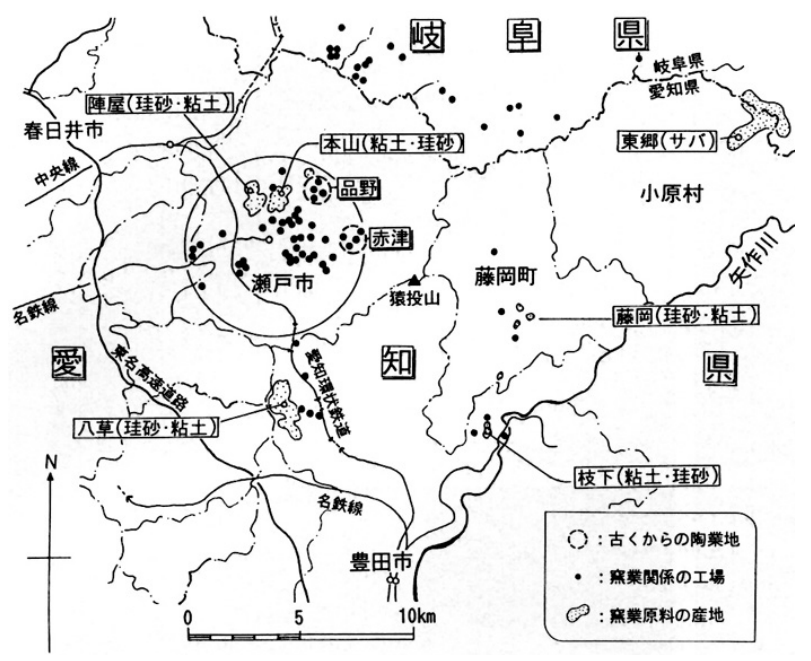

図-1 瀬戸市周辺の窯業と原料産地図 ${ }^{1)}$

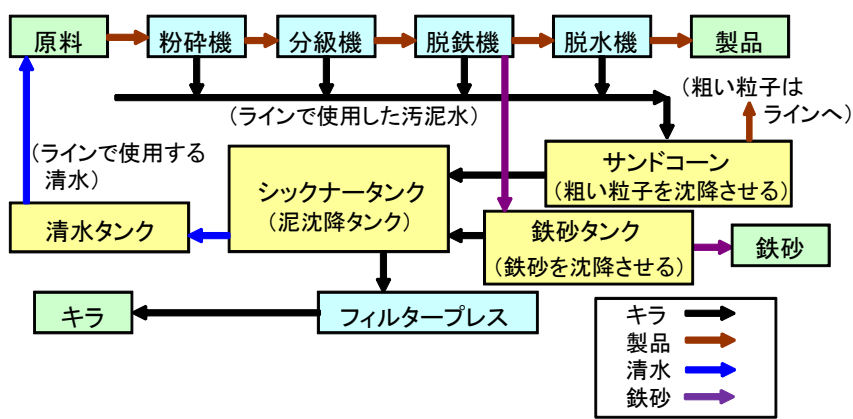

図-2 珪砂精製工程（キラの排出）

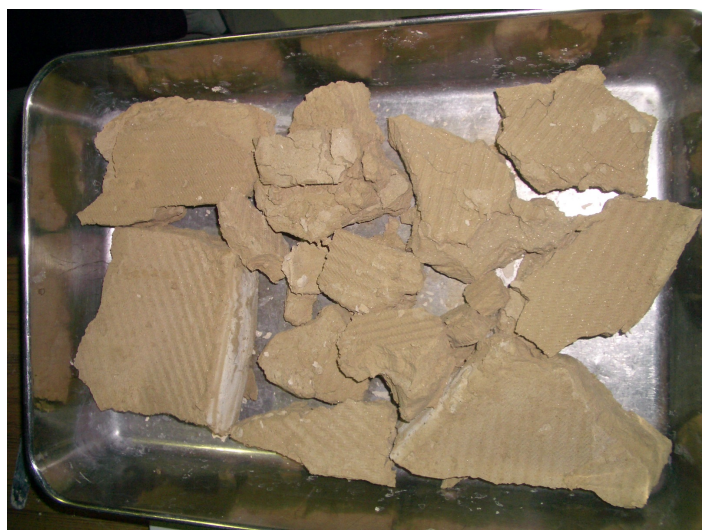

写真-1 脱水ケーキキラ

\section{(2) キラの物理的性質}

キラは, 通常の土材料と異なり, 珪砂精製過程とい う一次処理を経た材料である。ここではキラを地盤材 料と見なして, 必要に応じて典型的な砂 (珪砂 6 号) $\left.{ }^{4}\right)$ と典型的な粘土（粘土分 $60 \%$ 含有）と比較して, 物理 的性質を調べる. 
表-1 微粒珪砂キラの組成成分

\begin{tabular}{ccccc}
\hline $\mathrm{SiO}_{2}$ & $\mathrm{Al}_{2} \mathrm{O}_{3}$ & $\mathrm{Na}_{2} \mathrm{O}$ & $\mathrm{K}_{2} \mathrm{O}$ & $\mathrm{MgO}$ \\
70.9 & 16.8 & 0.5 & 5.2 & 0.5 \\
\hline $\mathrm{CaO}$ & $\mathrm{Fe}_{2} \mathrm{O}_{3}$ & $\mathrm{TiO}_{2}$ & Ig.Loss \\
0.9 & 2.1 & 0.3 & 2.76 \\
\hline & & & (単位：重量\%)
\end{tabular}

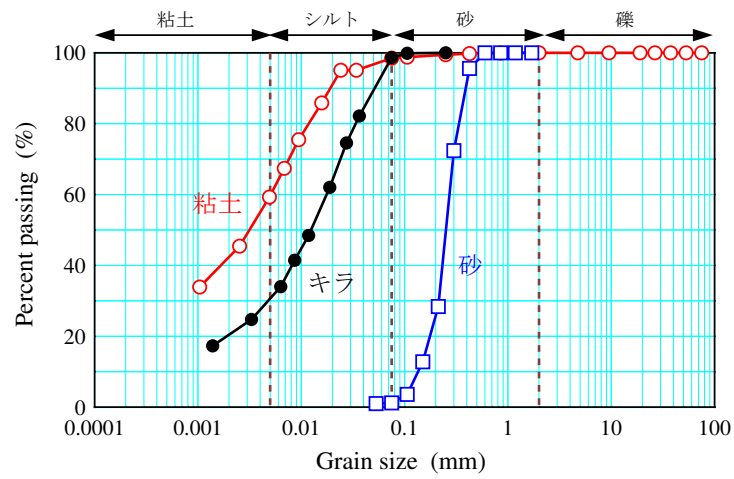

図-3 キラ, 粘土, 珪砂の粒径加積曲線

\section{a） キラの組成成分}

キラの組成成分を表-1 に示す. キラの主成分は $\mathrm{SiO}_{2}$ と $\mathrm{Al}_{2} \mathrm{O}_{3}$ で，それぞれ $70 \%$ 程度， $17 \%$ 程度を有してい る. その他, $\mathrm{Fe}_{2} \mathrm{O}_{3}$ は $2 \%$ 強, $\mathrm{CaO}$ は $1 \%$ 弱であり, 石 灰を入れることにより固化が期待できる組成成分を有 している10),11). 典型的な砂と組成成分を比較すると， 珪砂 6 号はシリカが $98 \%$ にもなり，キラとの組成成分 は異なることがわかる，また，キラは選別工程を経た ものであるため, 粒径, 組成成分などの品質面でも自 然材料の土と比べて均質化している. また, 天然の地 層から分離したもので, 重金属（カドニウム, 鉛, 砒 素など）などの有害物質はほとんど含まれておらず無 害で，環境面でも安心して使用できる資源である.

b) キラの土粒子密度・コンシステンシー・粒度分析 キラの粒径加積曲線を図-3 亿示す，比較のため, 粘 土および珪砂 6 号の曲線も併せて示した。 キラは粘土 分 $30 \%$, シルト分 $68 \%$, 砂分 $2 \%$ を含んでおり, 地盤 材料の工学的分類の基準によるとシルト (ML) に分類 される，キラの密度および液性限界・塑性限界試験結 果を表-2 にまとめた．キラはシルト分を多く含有する ため, 液性限界 $w_{L}$ は粘土に比べ小さく, 塑性指数 $I_{p}$ は 17.3 と低くなっている. 土粒子密度 $\rho_{s}$ については, 通常の地盤材料とほとんど同じ值を示す.

\section{c) キラの保水性}

地盤工学会基準 JGS 0151-2000 に準じて，キラの保水 性試験を実施した。試験容器は内径 $6.0 \mathrm{~cm}$, 高さ $2.5 \mathrm{~cm}$ の圧密箱を用い, 吸引法 (水頭法) で行った。後述す る締固め曲線での最大乾燥密度 $\rho_{d \max }=1.56 \mathrm{~g} / \mathrm{cm}^{3}$ を初
表-2 キラ, 粘土, 珪砂の各種物性

\begin{tabular}{l|ccc}
\hline & キラ & 粘土 & 珪砂 \\
\hline 初期含水比 $(\%)$ & 33.0 & - & - \\
液性限界 $w_{L}(\%)$ & 44.6 & 94.0 & - \\
塑性限界 $w_{p}(\%)$ & 27.3 & 34.6 & - \\
塑性指数 $I_{p}$ & 17.3 & 59.4 & - \\
土粒子密度 $\rho_{s}\left(\mathrm{~g} / \mathrm{cm}^{3}\right)$ & 2.62 & 2.65 & 2.65 \\
\hline
\end{tabular}

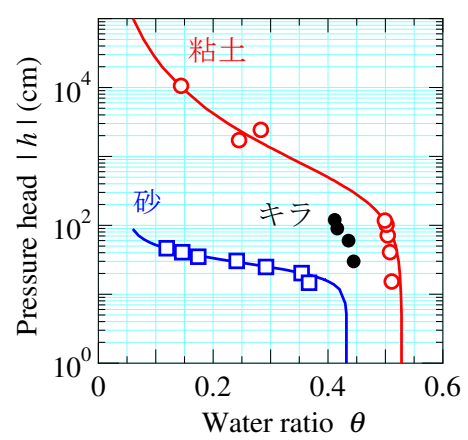

図-4 キラ，粘土，珪砂の水分特性曲線

期状態とし，1 日間毛管飽和させた。この飽和過程で キラはわずかな膨張が観察された。供試体下部に連結 しているビュレットを下げることにより水頭差を与え， 水頭差は供試体の中心位置を $h=0 \mathrm{~cm}$ として, $h=-30$, $-60,-90,-120 \mathrm{~cm}$ と変化させ，水分平衡に達し排水 が終了するまでそれぞれ約 6 時間放置した。保水性試 験により得られた水分特性曲線を図-4に示寸. 図-4の 縦軸は水頭差 $(\mathrm{cm})$ の絶対值である. 横軸は体積含水率 $\theta$ で，以下の式で表される.

$$
\theta=\left(\rho_{d} / \rho_{w}\right) \times w
$$

なお， $\rho_{d}$ はキラの乾燥密度， $\rho_{w}$ は水の密度， $w$ は含水 比である.

試験装置の関係上, 最大水頭差は $120 \mathrm{~cm}$ であったので, 水分特性曲線の一部となっている. 図中には砂や粘土の 曲線 ${ }^{12}$ を比較のため載せている. 砂は豊浦標準砂（土粒 子密度 $\rho_{s}=2.65 \mathrm{~g} / \mathrm{cm}^{3}, \mathrm{e}_{\max }=1.00, \mathrm{e}_{\min }=0.646$, 間隙率 $n=0.43)$ で, 粘土の物性は土粒子密度 $\rho_{s}=2.61 \mathrm{~g} / \mathrm{cm}^{3}$, $I_{p}=45.5$, 透水係数 $k=8.32 \times 10^{-7} \mathrm{~cm} / \mathrm{s}$, 間隙率 $n=0.528$ である.ここで示している典型的な砂と粘土は，表-2で 説明したものとは異なり, 文献 12)のデータを直接用 いている.

キラの間隙率は $n=0.490$ であり, 砂, 粘土のそれと 違いはあるものの, 両者と比較すると, 砂と粘土の中 間の保水性を有することがわかる．まず砂と比較する と, 砂は水頭差が $10 \mathrm{~cm}$ からわずかに増えると, 間隙水 を保持することが困難になり, 体積含水率が急激に低 下寸る．粒径が大きいため保水能力が低い，一方粘土 は, 粒径が小さく水頭差が $100 \mathrm{~cm}$ であっても初期の含 


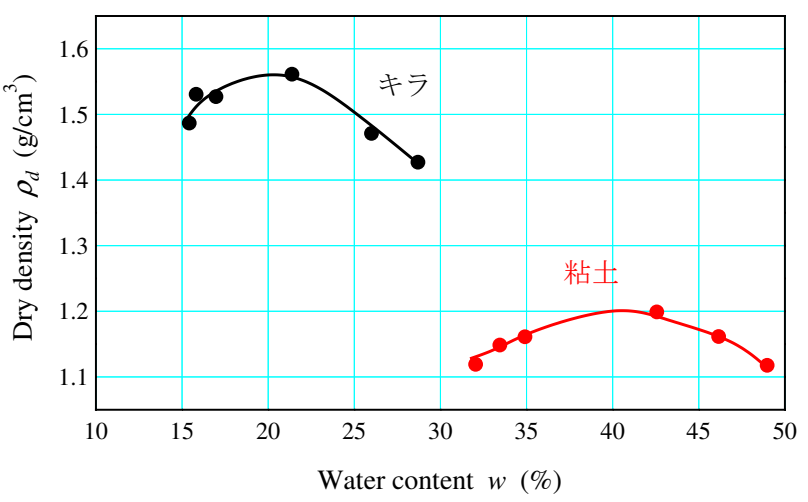

図-5 キラ, 粘土の締固め曲線

水率を保持し続ける. 水頭差 $1000 \mathrm{~cm}$ になったところ で含水率は半分になるが，まだ保持能力が残している. 水分特性曲線の勾配の大きく変化するところは, 保水 特性が大きく変化するところであるが，本実験からは 同定することができない.

\section{(3) キラの力学特性}

キラの力学特性を把握するため, まず締固め試験に より締固め特性を把握する。つぎに締固め試験で得ら れた最大乾燥密度でのキラと, 脱水ケーキキラの一軸 圧縮強度の比較を行う。さらに, 圧縮特性, せん断特性 を把握するため，標準圧密試験および三軸圧縮試験を 実施する。これら試験結果は，4. での SYS Cam-clay model の構成式応答による材料定数の決定にも用いら れる。

\section{a) 締固め特性}

図-5にキラの締固め曲線を示寸，脱水ケーキキラを 自然乾燥させ, JIS A 1210 に従い, 締固め方法 A-a 法 に準拠した突固めによる締固め試験を実施した。 最適 含水比 $w_{o p t}$ は $21 \%$, 最大乾燥密度 $\rho_{d \max }$ は $1.56 \mathrm{~g} / \mathrm{cm}^{3}$ となり, 脱水ケーキキラ産出時の含水比 $w=33 \%$ あた りでは, 突固めの際のランマーの衝撃荷重により供試 体を作製することができなかった.

同図には粘土の締固め曲線も示している. 最適含水 比 $w_{o p t}=40 \%$ で最大乾燥度 $\rho_{d \max }=1.20 \mathrm{~g} / \mathrm{cm}^{3}$ を示し た。粒径の違いにより, キラと比べ含水比は高く乾燥 密度はかなり低くなっており, さらにキラの締固め曲 線よりも形状がなだらかである。

\section{b) 一軸圧縮強度}

得られた締固め曲線の最適含水比 $w_{o p t}$ と脱水ケーキ キラ産出時の含水比 $w=33 \%$ の 2 つの状態に対し, JIS A 1216 に従い，一軸圧縮試験を実施した。供試体寸法 は直径 $5.0 \mathrm{~cm}$, 高さ $10.0 \mathrm{~cm}$ で締固めにより供試体を作 製した。ただし脱水ケーキキラについては静的に締固め ることにより作製している. 脱水ケーキキラは湿潤密度

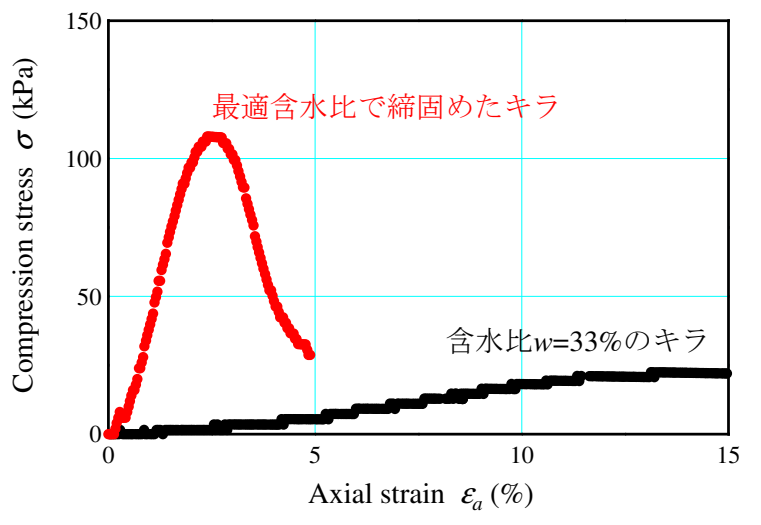

図-6 $w=33 \%$ と $w_{o p t}$ のキラの一軸圧縮強度

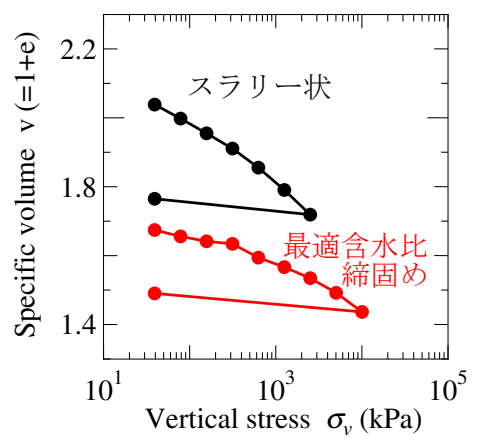

図一7 スラリー状と $w_{o p t}$ で締固めたキラの圧縮特性

$\rho_{t}=1.82 \mathrm{~g} / \mathrm{cm}^{3}$, 飽和度 $S_{r}=95 \%$ であった. 図-6 に圧 縮応力〜圧縮ひずみ関係を示している. 脱水ケーキキラ 産出時の一軸圧縮強度は $25 \mathrm{kPa}$ 程度で, この状態のま までは地盤材料として利用することはできない，一方， 最適含水比まで調整したキラは一軸圧縮強度が $100 \mathrm{kPa}$ を超えており，用途に応じて，土構造物として利用する ことができる材料になっている. しかし，保水性試験 の飽和化の過程において, キラは最適含水比で締固め ても周りから十分な水が供給されると, 短時間で膨潤 が観察されている．定量的には計測していないが，圧 密リングに最適含水比, 最大乾燥密度になるよう成形 し，下から給水し飽和化させたところ，1 日放置すると 1〜2mm 程度膨潤した。 この膨潤はキラの密度を小さ くし, 強度を低下させると推測される.

\section{c) 圧縮特性一標準圧密試験結果}

図-7にはキラの標準圧密試験結果を示す．初期に高 含水比を有するスラリー状のキラと最適含水比で締固 めたキラの 2 つの試料を用いた，スラリー状のキラと は, 液性限界 $\left(w_{L}=44 \%\right)$ の 2 倍程度の含水比で練り 返して作製した試料のことで, 以後スラリー状キラと よぶ. スラリー状キラは初期に高含水比を有するため, 圧縮線は若干上に凸を描き, 先行圧密圧力は現れてい ない. また最適含水比で締固めた試料は, 圧縮性が小 さく，過圧密土であることがわかる．粘土の圧縮特性 

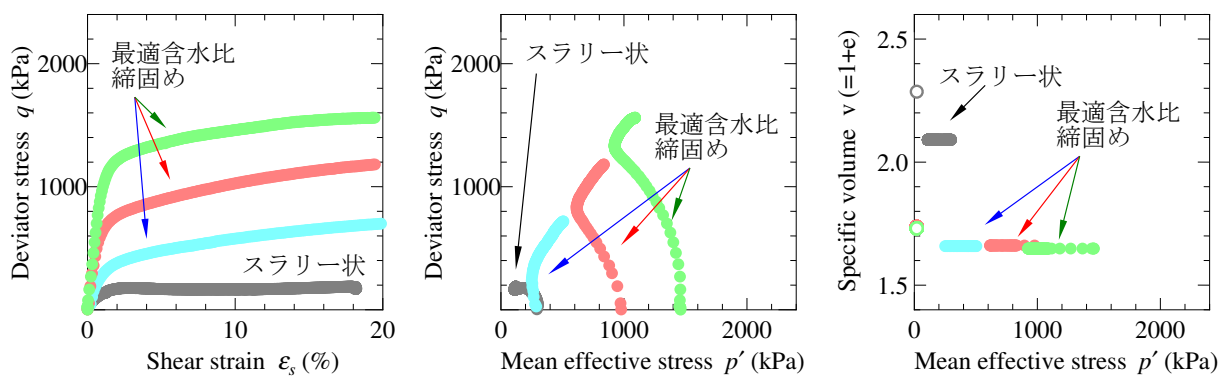

図-8 スラリー状と $w_{o p t}$ で締固めたキラの非排水三軸圧縮試験結果

よりも低く, 砂の圧縮特性に近い. 各載荷段階の透水 係数 $k$ は，両試料ともにばらつくものの $10^{-6} \mathrm{~cm} / \mathrm{s}$ 前 後となっており，砂代替材としては低い透水性である.

\section{d) せん断特性一非排水三軸圧縮試験結果}

図-8 は，スラリー状キラおよび最適含水比で締固 めたキラの三軸圧縮試験結果である．スラリー状キラ は, 拘束圧 $294.3 \mathrm{kPa}$ で 24 時間等方圧密した後, ひ ずみ速度 $9.0 \times 10^{-3} \mathrm{~mm} / \mathrm{min}$ で非排水せん断した。最 適含水比で締固めたキラは，最適含水比 $w_{o p t}=21.4 \%$, 最大乾燥密度 $\rho_{d \max }=1.56 \mathrm{~g} / \mathrm{cm}^{3}$ になるように突固め た供試体を作製し, 以後十分に通水を行い飽和化させ た. 拘束圧は $294.3 \mathrm{kPa}, 981.0 \mathrm{kPa}, 1471.5 \mathrm{kPa}$ の 3 パ ターンでそれぞれ 24 時間等方圧密した後, ひずみ速度 $7.0 \times 10^{-3} \mathrm{~mm} / \mathrm{min}$ で非排水せん断した. スラリー状キ ラに関して, せん断初期に平均有効応力 $p^{\prime}$ が減少しな がら軸差応力 $q$ が増加して, その後 $p^{\prime}$ の減少を伴う $q$ の減少を示し, さらにその後, 若干ではあるが $p^{\prime}$ の増 加に伴う $q$ の増加を示している. スラリー状キラのせ ん断挙動はゆる詰め〜中詰め砂の非排水せん断挙動に 類似している. 一方最適含水比で締固めたキラについ ては, どの拘束圧のときでも, せん断初期に $p^{\prime}$ が減少 しながら $q$ が増加した後, $p^{\prime}$ が増加に転じながら $q$ は 増加し続ける挙動を示している. これは密詰め砂の非 排水せん断挙動に類似している.

\section{3. 破砕・石灰混合・締固めにより改良され たキラの力学特性}

2. で示したように珪砂キラは，未改良の脱水ケーキ 状態では良好な地盤材料とはなり得ず, なんらかの改 良を施す必要がある。改良の方法は 2 つあり, 一つは 2. で示したように最適含水比まで調整し締固め, 材料 の状態, 密度を変化させる方法と, もう一つは石灰等 の固化材を混合することにより，材料の性質を変化さ せる方法である. 前者の締固めのみの改良では, 締固 めるためにキラを乾燥させる必要があり, また締固め た後であっても水の浸入などにより密度が減少し, 強

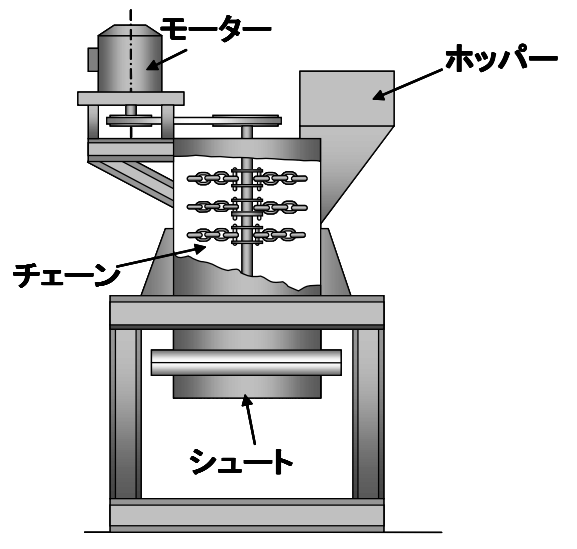

図-9 破砕混合機の概要図

度が下がることが予想される。一方, 後者の改良方法 では, キラの組成成分から石灰により改良効果が上昇 することが推測される10),11)ため，ここでは生石灰によ る改良を採用する。なお石灰混合直後の強度を, 国土 交通省の土質利用区分の第 3 種建設発生土を満足する 強度と設定し, 予備実験により石灰配合率をキラ乾燥 重量に対し $3 \%$ とした。

固化材混合による改良土の場合, より均質に固化材 を混合することで, 改良効果は著しく上昇する.ここで は脱水ケーキ状材料を, 極めて均質に, そして瞬時に固 化材と混合し，同時に団粒化させることのできるチェー ン回転式破砕混合機 2 )（以降，破砕混合機とよぶ）を用 いる.この破砕混合機により石灰均質混合のキラの粒 状集合体を作製した. 破砕混合機の概要を図一9に示す. $11 \mathrm{~kW}$ のモーターにより, 混合室の回転軸が回転する. 混合室の寸法は直径 $500 \mathrm{~mm}$, 高さ $700 \mathrm{~mm}$ である. 回 転軸には， 1 層につき 4 本のチェーンが 3 層, 計 12 本 設置されている.モーターの駆動によってチェーンが 水平方向に高速回転し, それにより発生する打撃力で, ホッパーから投入された地盤材料を細粒化するととも に均質に混合し，シュートより排出する. チェーン回 転数は，0～900r.p.m. で，任意に設定できる.今回は， 最も破砕しやすく均等に石灰が混合できる回転数とし て, 600r.p.m. に設定した. 


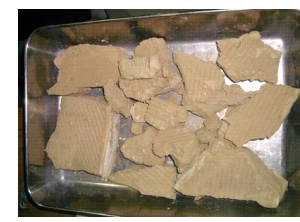

脱水ケーキキラ

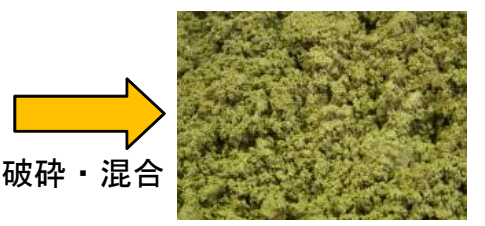

粒状集合体
写真-2 脱水ケーキキラと破砕後の粒状集合体

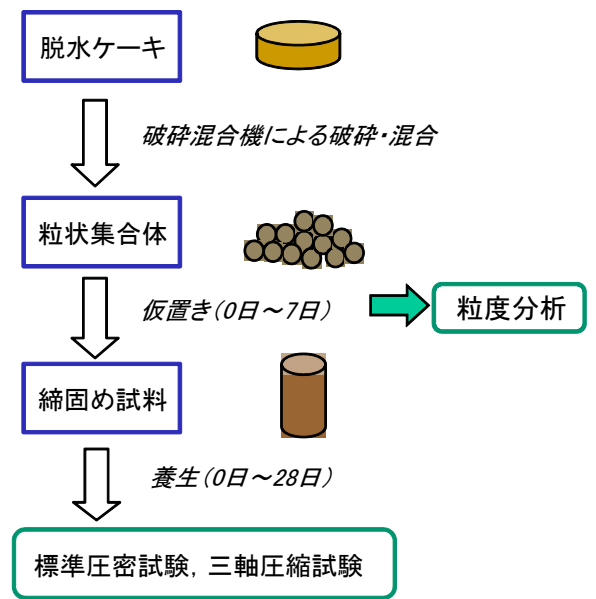

図-10 キラ改良土作製過程のフロー図

破硪混合機により粒状化した石灰均質混合のキラ集 合体を写真-2に示寸．この粒状集合体を仮置きした後 に締固め，さらに養生して供試体を作製する（以下，キ ラ改良土とよぶ) 。仮置きとは締固め前に放置すること で, 養生とは締固め後に密閉して乾燥しないようにし て放置することである. 仮置き日数は最大 7 日（一部 28 日）まで, 養生日数は 28 日までとした. 改良土作製 と試験のフローを図-10に示す。このように作製した キラ改良土に対し, 各種物理・力学試験を実施した。

（1）粒度分布一未改良キラとキラ改良土の粒度の比較 破砕混合機により粒状化した石灰均質混合のキラ集 合体を十分に乾燥させると粒状を保ち, キラ集合体の 粒度分析が可能となる. 図-11に未改良キラと, 破砕・ 石灰混合により粒状化したキラ改良土の粒径加積曲線 を示す．未改良キラはシルトを中心に細粒分が 9 割以 上占めていたのに対し, キラ改良土は固化材により改 良することで見かけの粗粒分が約 9 割になった.

\section{（2）仮置き日数と含水比, 乾燥密度, 一軸圧縮強度の 関係}

破砕・石灰混合後のキラ粒状体に対し，仮置きがその 後の強度特性にどのような影響を与えるかを示す。養 生日数の効果を排除するため, 締固め後に養生しない （養生日数 0 日）供試体に対する, 仮置き日数と含水比, 乾燥密度, 一軸圧縮強度の関係を図-12 に示寸. 含水

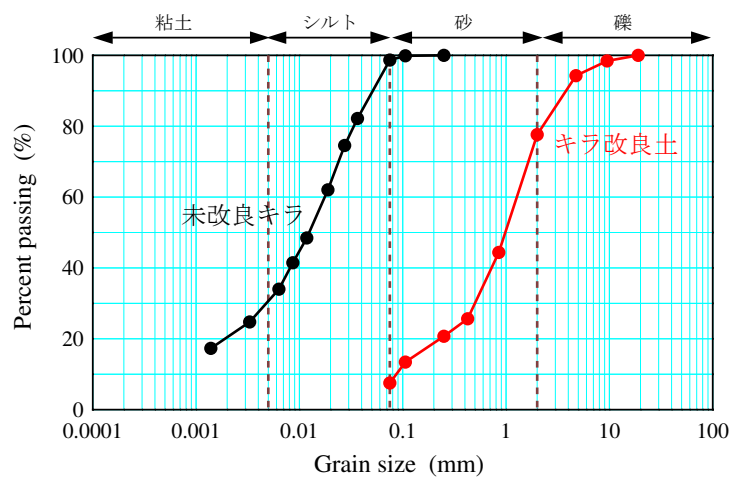

図-11 未改良キラとキラ改良土の粒径加積曲線
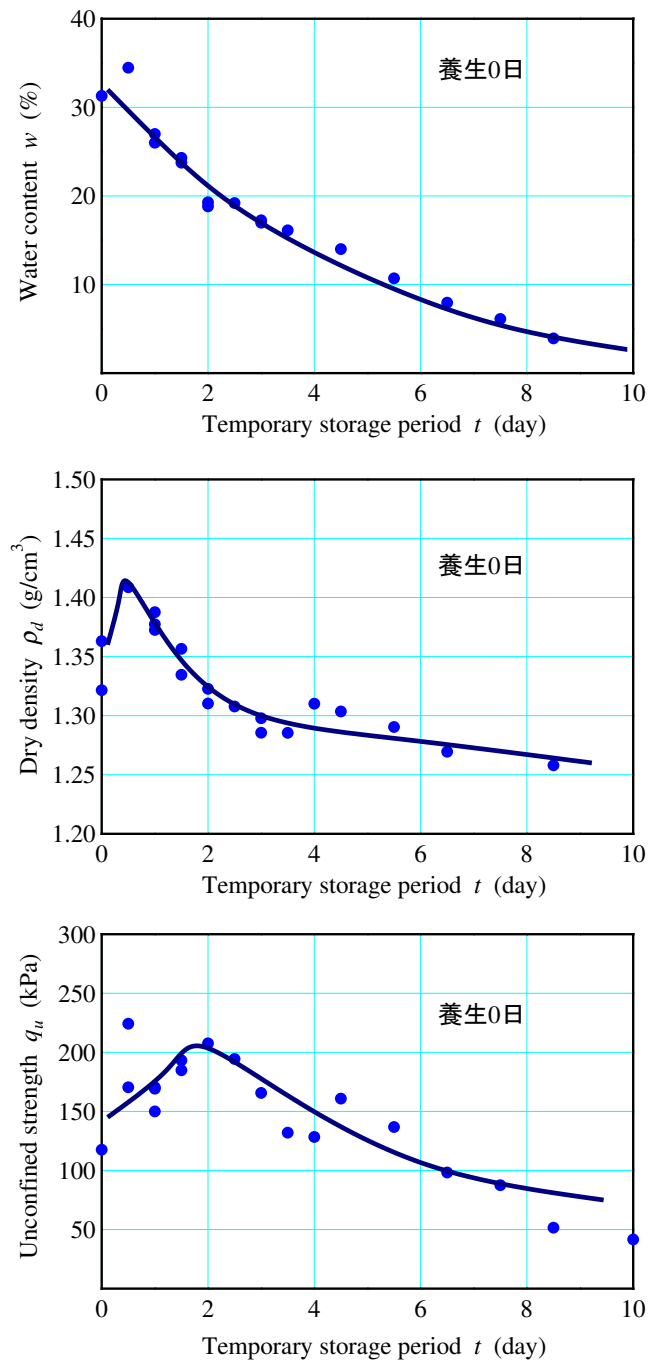

図-12 仮置き日数が含水比, 乾燥密度, 一軸圧縮強度に及ぼ す影響（養生 0 日の場合）

比〜仮置き日数関係から仮置き日数が増えるにつれ含 水比が減少している. また乾燥密度 $\rho_{d}$ は仮置き日数が 半日ぐらいで最大となり, その後減少している。一軸圧 縮強度は, 仮置き日数が 2 日で最大となり, その後は 減少している。仮置きは, 団粒化した改良土粒自身の 固化を進展させる働きがあり，仮置き時間が長すぎる と粒自身が固くなり, 締固めしづらい材料になる. 今回 


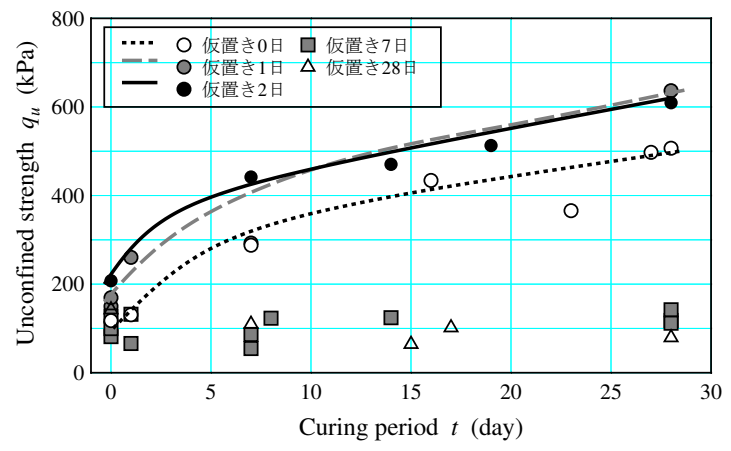

図-13 養生, 仮置きが一軸圧縮強度に及ぼす影響

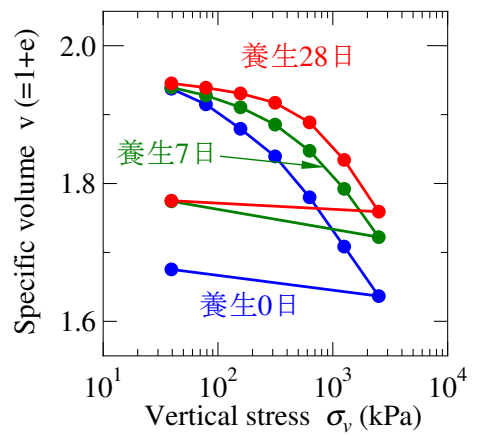

図-14 キラ改良土の圧縮性に及ぼす養生日数の影響
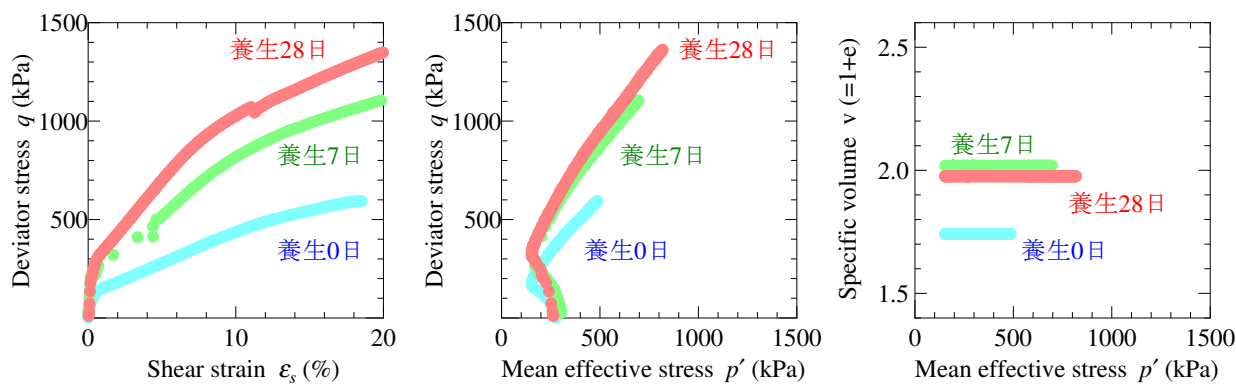

図-15 養生日数の異なるキラ改良土の非排水三軸圧縮試験結果

の試験条件では, 改良土粒が固化しすぎず，かつ締固 めやすい材料になる仮置き日数が 2 日であったことが 推察される。つまり現場においては, 破砕混合機で石 灰混合した材料は，長期間仮置きせずに，破砕後 2 日 以内には締固める必要がある.

\section{（3）養生日数が一軸圧縮強度，圧縮特性，せん断特性 に及ぼす影響}

\section{a) 一軸圧縮強度}

キラ改良土の養生による強度増進の効果を示す. 図一 13 は仮置き期間を変え作製した供試体が発揮する一軸 圧縮強度に及ぼす養生日数の影響を示したものである. 仮置き期間は 0 日， 1 日， 2 日， 7 日， 28 日に設定した。 仮置きが 0 日， 1 日， 2 日の短期間の試料はいずれも突 固め後に養生の効果が見られ, 著しく強度が増加した. 仮置きなしにおける一軸圧縮強度は，28 日養生により $500 \mathrm{kPa}$ まで上昇し，0 日養生の約 5 倍になっている. これに対し，仮置きが 7 日，28 日と長期間の試料では 養生の効果がなかった。この理由は仮置き期間のうち にキラの粒において石灰の初期反応がほぼ終了したた めと考えられる.

\section{b) 圧縮特性}

図-14 に，仮置き 0 日とし，養生 0 日，7日，28日の 養生期間のキラ改良土の標準圧密試験結果を示寸。養 生 28 日により圧縮量はかなり改善され，養生 0 日の 2 分の 1 程度になる。 また養生により, 見かけの圧密降
伏応力 が増加している.つまり載荷除荷の荷重履歴を 経ず，養生により過圧密土になったとみなすことがで きる.このことについては 4. で SYS Cam-clay model を用いて骨格構造の働きに注目し解釈する.

\section{c) 非排水三軸圧縮試験}

図-15 に，仮置き 0 日とし，養生 0 日，7日，28 日 のキラ改良土の三軸圧縮試験結果を示す. 破砕混合機 により, 破砕・石灰混合した試料を締固めエネルギー 一定のもと締固めて供試体を作製している。キラ改良 土は締固め後, 等方圧 $294 \mathrm{kPa}$ で等方圧密した後, 側圧 一定で非排水せん断した。養生日数に応じて初期剛性 が大きくなり, 最大軸差応力は増加した. 有効応力パ ス（平均有効応力 $p^{\prime}$ ～軸差応力 $q$ 図）を見ると, $p^{\prime}$ は 減少後, 増加に転じるが, その後の $q$ の硬化の度合い は養生日数の増加とともに大きくなる.

\section{SYS Cam-clay modelに基づく破砕 - 石灰混合 · 締固めによるキラの改良効果 の把握}

改良土の力学挙動に及ぼす改良効果, 特に養生の効 果について, 骨格構造概念を考慮した弾塑性構成モデル である SYS Cam-clay model を用いて考察する. SYS Cam-clay model の概要は付録 I で説明するが，本モデ ルは, 骨格構造, 寸なわち構造, 過圧密, 異方性の発 展を考慮することにより, 砂から中間土, 粘土にいた 


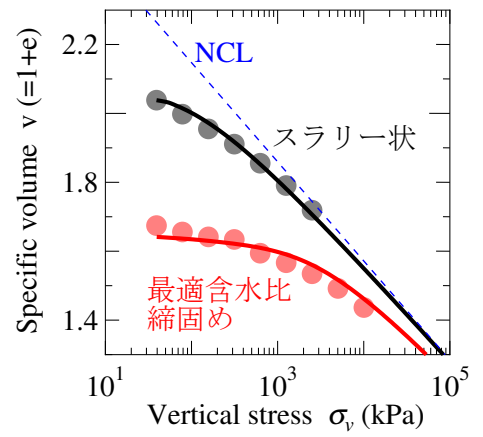

図-16 SYS Cam-clay modelによる未改良キラの標準圧密 試験の再現 (一次元圧縮応答)
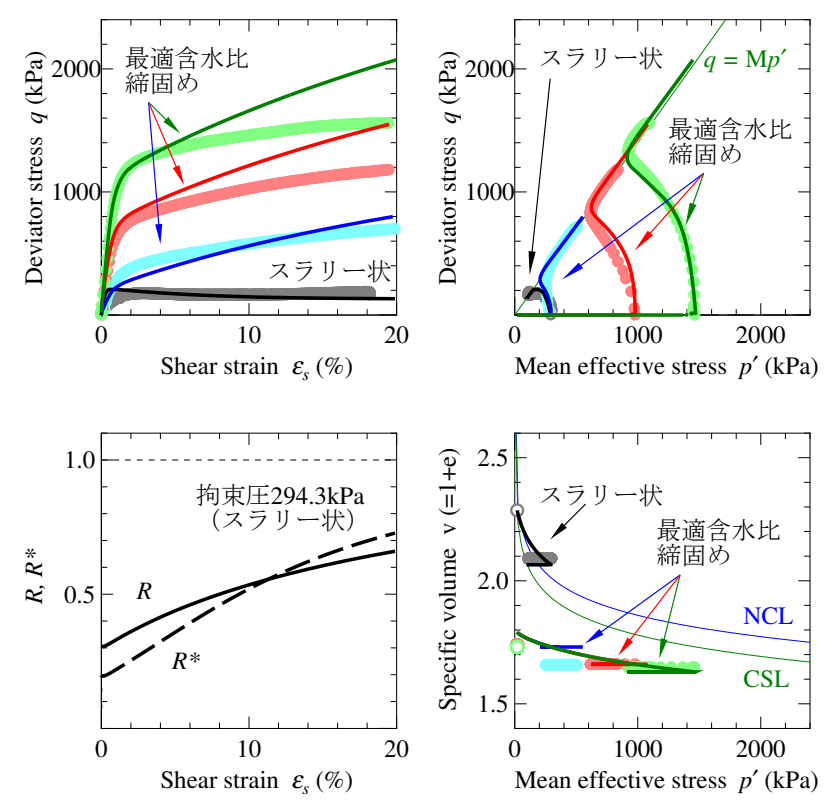

図-17 SYS Cam-clay model による未改良キラの非排水三 軸圧縮試験の再現

る力学挙動の違いを弾塑性力学に基づいて説明するこ とができる，詳細は文献に譲るが，塑性変形に応じて， 粘土は過圧密喪失が構造劣化より速く進行し, 砂では 構造劣化が過圧密喪失よりも速く進行する ${ }^{4), 13)}$ として いる.なお「構造」とは, 自然堆積土の圧縮線と練り 返した同じ土の圧縮線の間隙比の違い，嵩張り具合を 示し，モデルでは，構造の程度を $1 / R^{*}$ で表し， $R^{*}$ は 0 から 1 の值をとる. $R^{*}$ が 0 に近いほど高位な構造を 有し，1 に近いほど低位な構造，才なわち練返し状態に 近づく. 過圧密については, $1 / R$ が過圧密比に対応し, $1 / R$ が大きいほど, 過圧密比が大きい, 超過圧密土を 表す4).

\section{（1）未改良キラのカ学挙動の再現と骨格構造の働きに 基づく解釈}

まず未改良キラの力学挙動に対し, 軸対称条件下で の SYS Cam-clay model の構成式応答による再現を示
表-3 未改良キラ，キラ改良土の材料定数

\begin{tabular}{lcc}
\hline <弾塑性パラメータ> & & \\
\hline 圧縮指数 $\tilde{\lambda}$ & 0.15 & \\
膨潤指数 $\tilde{\kappa}$ & 0.02 & \\
限界状態定数 $\mathrm{M}$ & 1.4 & \\
NCL の切片 $\mathrm{N}$ & 2.15 & \\
$\quad\left(\right.$ at $\left.p^{\prime}=98.1 \mathrm{kPa}\right)$ & & \\
ポアソン比 $\nu$ & 0.3 & \\
\hline \hline <発展則パラメータ> & 未改良 & キラ \\
& キラ & 改良土 \\
\hline 正規圧密土化指数 $m$ & 0.3 & 0.05 \\
構造劣化指数 $a$ & 2.0 & 0.1 \\
構造劣化指数 $b$ & 0.01 & 1.0 \\
構造劣化指数 $c$ & 1.5 & 1.0 \\
構造劣化指数 $c_{s}$ & 0.9 & 0.9 \\
回転硬化指数 $b_{r}$ & 0.05 & 0.05 \\
回転硬化限界定数 $m_{b}$ & 0.5 & 0.5 \\
\hline
\end{tabular}

\section{表-4 標準圧密試験の初期值}

\begin{tabular}{l|c|ccc}
\hline & 未改良 & \multicolumn{3}{|c}{ キラ改良土 } \\
\cline { 3 - 5 } 養生日数 & キラ & 0 日 & 7 日 & 28 日 \\
\hline 比体積 $\mathrm{v}_{0}$ & 2.04 & 1.94 & 1.94 & 1.94 \\
有効忘力 $p_{0}^{\prime}(\mathrm{kPa})$ & 39.2 & 39.2 & 39.2 & 39.2 \\
過圧密比 $1 / R_{0}$ & 9.5 & 43.4 & 86.9 & 134.1 \\
構造の程度 $1 / R_{0}^{*}$ & 1.4 & 3.0 & 6.0 & 10.0 \\
異方性 $\zeta_{0}$ & 0.0 & 0.0 & 0.0 & 0.0 \\
\hline
\end{tabular}

表-5 非排水三軸圧縮試験の初期值

\begin{tabular}{l|c|ccc}
\hline & 未改良 & \multicolumn{3}{|c}{ 改良土 } \\
\cline { 3 - 5 } 養生日数 & キラ & 0 日 & 7 日 & 28 日 \\
\hline 比体積 $\mathrm{v}_{0}$ & 2.29 & 1.90 & 2.02 & 2.01 \\
有効応力 $p_{0}^{\prime}(\mathrm{kPa})$ & 19.6 & 19.6 & 19.6 & 19.6 \\
過压密比 $1 / R_{0}$ & 20.2 & 48.2 & 243.7 & 338.4 \\
構造の程度 $1 / R_{0}^{*}$ & 10.0 & 1.1 & 14.0 & 18.0 \\
異方性 $\zeta_{0}$ & 0.0 & 0.0 & 0.0 & 0.0 \\
\hline
\end{tabular}

す. 構成式応答による力学試験結果の再現を示す図中 では, 太線は力学試験結果を, 細線は構成式応答による 再現を表している. 図-16 は未改良キラの標準圧密試 験（図-7）に対する再現を, 図-17 は三軸圧縮試験結 果（図-8）に対する再現を示す. SYS Cam-clay model は標準圧密試験での圧縮線をうまく再現している。軸 圧縮試験に関しては, せん断後半の $q$ を高く見積もって いるものの, SYS Cam-clay model はスラリー状キラか ら最適含水比で締固めたキラまで, 拘束圧の異なる試験 についてもよく再現している. なお最適含水比での締 固めは，スラリー状キラを初期状態として排水繰返し せん断によって表現している.これにより決定した材 料定数を表 -3 に, 標準圧密試験の初期值を表-4に, 三 軸圧縮試験の初期值を表 -5 に示した。 未改良キラの圧 密試験，三軸試験の初期状態において $R_{0}, R_{0}^{*}$ の值が異 
なっている，この理由は，供試体作製における避けら れないばらつきや供試体作製方法に起因する応力経路, 応力状態の違いと推察している，なお表には，後に未 改良キラであるスラリー状キラとキラ改良土とを比較 するため両者ともに示している.

ここで，表-3に示寸発展則パラメータについて説明 を加える． $R^{*}$ および $R$ の発展則は付録 $\mathbf{I}$ に示したが, $R^{*}$ の発展則を式 $(2)$ に示す.

$$
\begin{gathered}
\dot{R}^{*}=J U^{*}\left\{\left(1-c_{s}\right)\left(-\operatorname{tr} \boldsymbol{D}^{p}\right)+c_{s} \sqrt{\frac{2}{3}}\left\|\boldsymbol{D}_{s}^{p}\right\|\right\}, \\
U^{*}=\frac{a}{\mathrm{D}} R^{* b}\left(1-R^{*}\right)^{c}
\end{gathered}
$$

ここに, $\mathrm{D}=(\tilde{\lambda}-\tilde{\kappa}) / \mathrm{M} /\left(1+\mathrm{e}_{0}\right)$ はダイレイタンシー 係数, $J=(1+\mathrm{e}) /\left(1+\mathrm{e}_{0}\right) \quad(\mathrm{e}$ は時刻 $t=t$ での間隙 比, $\mathrm{e}_{0}$ は初期間隙比）, $\operatorname{tr} \boldsymbol{D}^{p}, \boldsymbol{D}_{s}^{p}$ はそれぞれ塑性ス トレッチング $\boldsymbol{D}^{p}$ の体積成分と偏差成分を表す.

式 (2) における $U^{*}$ は $a, b, c$ を係数とした $R^{*}$ の関 数となっている. つまり構造劣化指数 $a, b, c$ によって 構造劣化のし易さが変化する. また構造劣化指数 $c_{s}$ は, その值を $0 \sim 1$ の間でとり，1 亿近いほど塑性せん断ひ ずみによる構造劣化が卓越し，0 に近いほど塑性体積ひ ずみによる構造劣化が卓越する指標となっている。一 方, 式 (I.5) に示したように, 正規圧密土化指数 $m$ が 大きいほど過圧密の解消が速くなる（正規圧密土にな りやすくなる).

図-17 のR, $R^{*} \sim \varepsilon_{s}$ （せん断ひずみ）関係は，表 -3 ， 表-5 考用いたスラリー状キラの非排水せん断試験の構 成式応答から得られているが，この図から，せん断変 形に応じて過圧密解消速度 (すなわち正規圧密土化速 度）と構造劣化速度がほぼ同程度であることがわかる。 キラはシルト（ML）に分類され，砂と粘土の中間的な 材料であることを, 材料定数, 特に発展則パラメータ から示すことができた.

なお，図-17 の実験結果の再現と表 $-3 \sim$ 表 -5 の材料 定数の決定方法について簡単に述べる. SYS Cam-clay model は土の骨格構造が外力によってどのように変化 してゆくかを表現するモデルである。したがって土の もつ骨格構造, すなわち初期の構造, 過圧密の程度は, 構造，過圧密のない正規圧密土がその基準となり，まず 構造, 過圧密のない正規圧密土の力学試験から, 弾塑 性パラメータを決定する. そして発展則パラメータに は, それぞれ構造劣化のしやすさ, 正規圧密土のなり や寸さなどの物理的意味があるが, 実験から直接, そ れぞれのパラメータを決定することは困難なため, 乱 れの少ない土に対し, 状態を変えて, つまり拘束圧に よる比体積を変えてせん断試験を行うとともに, 圧密 試験も行い, その力学挙動を表現するパラメータを決 めている.

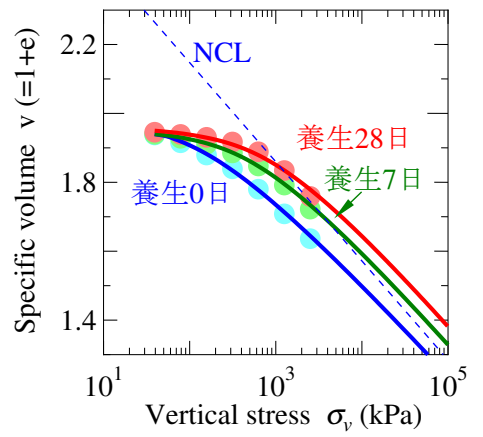

図-18 SYS Cam-clay model によるキラ改良土の標準圧密 試験の再現（一次元圧縮応答）

\section{（2） キラ改良土の力学挙動の再現と骨格構造の働きに 基づく解釈}

つぎにキラ改良土の力学挙動に対し, 軸対称条件下で の SYS Cam-clay model の構成式応答による再現を示 す. 図-18 はキラ改良土の標準圧密試験（図-14）に対 する再現を, 図-19〜図-21 は三軸圧縮試験結果（図一 15 ）に対する再現を，それぞれ養生日数ごとに示す. 表 -4 , 表 -5 に養生日数ごとの初期值を, それぞれ標準 圧密試験と三軸圧縮試験に対して示す.

キラ改良土の力学挙動の再現において, 本研究では, 破砕, 石灰混合, 締固めとその後の養生による改良をキ ラの骨格構造の発展に及ぼす効果として捉えている. 表-3で示した未改良キラの力学挙動の再現によって決 定した弾塑性パラメータは, 改良後も変化させず, 骨 格構造の程度・発展を測定する基準としている. 寸な わち破砕・石灰混合・締固めの効果を表 -4 , 表 -5 の構 造, 過圧密の初期值および, 表 -3 の発展則パラメータ の変化で表現し, 養生の効果を表 -4 , 表 -5 の構造, 過 圧密の初期值の変化で表現した。さらに改良土におい て, 異方性に関する働きは, 構造, 過圧密の働きに比 べ小さいと考え, 本論文では骨格構造の中でも, 構造 と過圧密のみに注目している.

改良土の力学挙動の再現には, 改良後の力学挙動に 対し弾塑性パラメータを決定, 表現する方法もある. し かしその場合, 改良前後での力学挙動の違いを弾塑性 パラメータの違いで表現できても, その違いが何に起 因しているかについては, 直接的回答は得られない, 本 研究では, 改良効果を骨格構造概念に基づいて考察す ることが主たる目的であり, そのため, 弾塑性パラメー 夕を改良前のキラの力学挙動の再現から求め, 改良後 も一定としている.

再現計算から, 未改良キラに比べてキラ改良土は, 構 造劣化しにくく, 過圧密が若干ではあるが解消しにく い材料に転化したことがわかった。 キラ改良土の発展 則パラメータに注目すると, 構造劣化速度は典型的な 粘土に類似しているが，過圧密解消速度は典型的な砂 

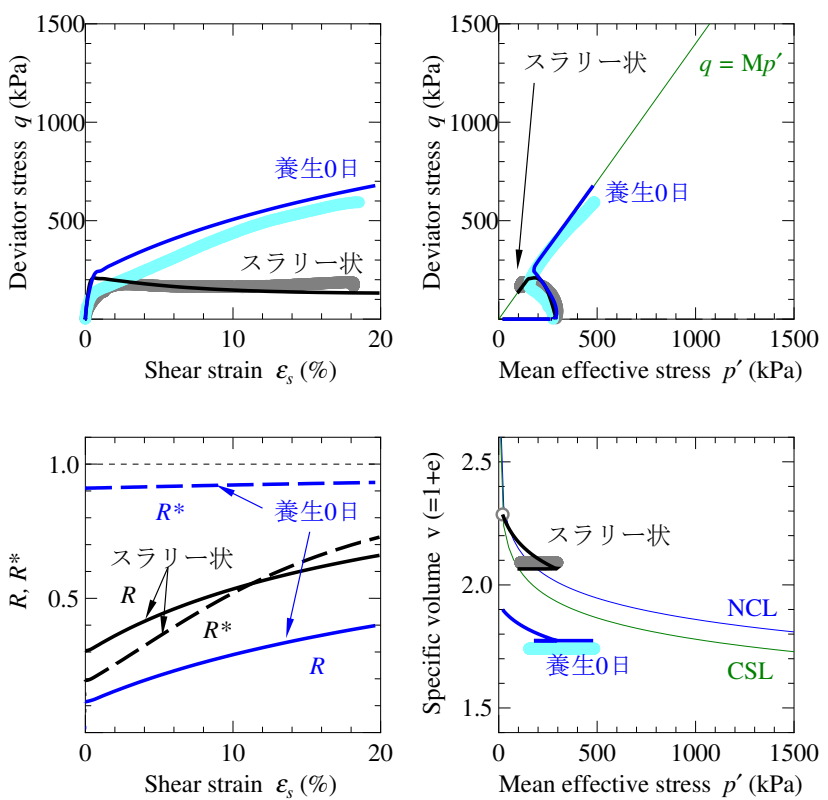

図-19 SYS Cam-clay model によるキラ改良土（養生 0 日） の非排水三軸圧縮試験の再現

に類似している ${ }^{13)}$ 。一方, 表-4, 表 $-\mathbf{5}$ から, 養生日数 に応じて, 構造, 過圧密の初期值が大きく変化し, 構造 は高位化する（ $R^{*}$ が減少する）とともに，過圧密比が 大きくなる $(R$ が減少する $)$.上記のことは, 図-19〜 図-21 の $R, R^{*} \sim \varepsilon_{s}$ 図のせん断ひずみ $\varepsilon_{s}$ が $0 \%$ におけ る $R, R$ の值からも確認できる. なお，表-4，表-5に おいて，おのおのの養生期間に対する構造と過圧密の 值が違っている．その原因としては，各供試体の作製時 の避けられないばらつきや，養生期間における異なる 境界条件下での固化作用を伴う応力履歴の違いや，供 試体内部の不均質性による固化作用のばらつきなら゙が 挙げられる，本研究においては，固化作用による改良 効果を骨格構造概念に基づいて説明することが主眼と なっており，供試体のばらつきや固化作用を伴う応力 履歴の検討は今後の課題としたい。同図から，養生に より構造は高位化するものの, せん断によりほとんど 劣化していないので，あたかも養生により，密な砂の 挙動を呈しているように見える。しかし養生により構 造が高位化した改良土は，いくら振動を与えても構造 が劣化しにくいため, 砂のように締固めによる大沈下 は示さない. 荷重履歴を与えていないのに, 過圧密比 が増加する理由は，構造高位化に伴う擬似過圧密とし て説明できる ${ }^{14)}$. 図-14 の標準圧密試験結果において, 養生日数が増えるにつれて, 見かけの圧密降伏応力が 大きくなっている理由は，養生により構造高位化とと もに，過圧密比も増加したからである。

最適含水比で締固めたキラ未改良土に比べて，キラ 改良土の方が密度が小さい（比体積が大きい）にもか
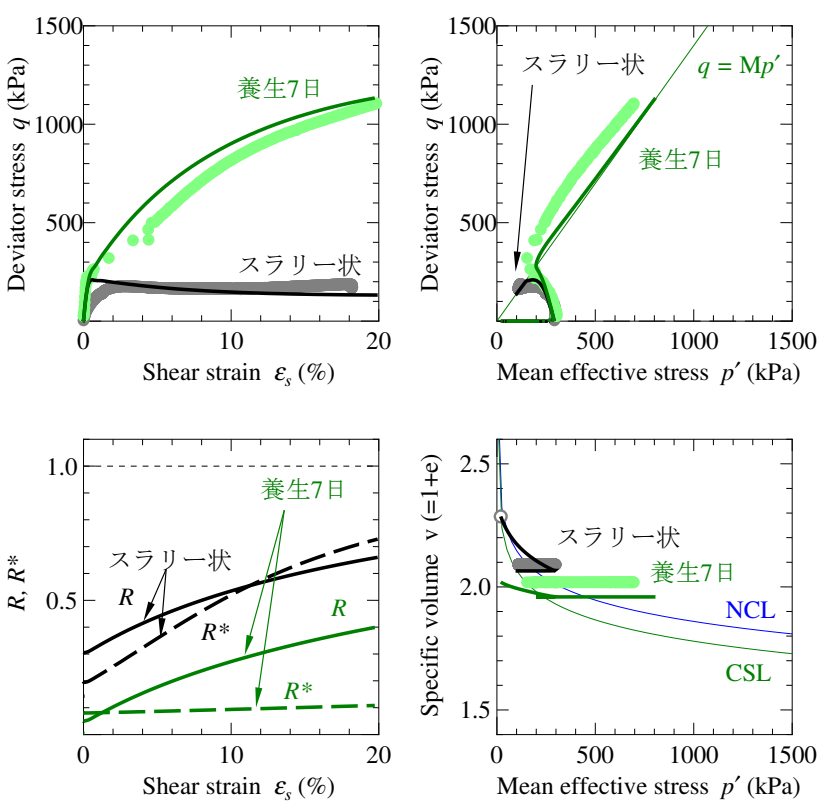

図-20 SYS Cam-clay model によるキラ改良土（養生 7 日） の非排水三軸圧縮試験の再現
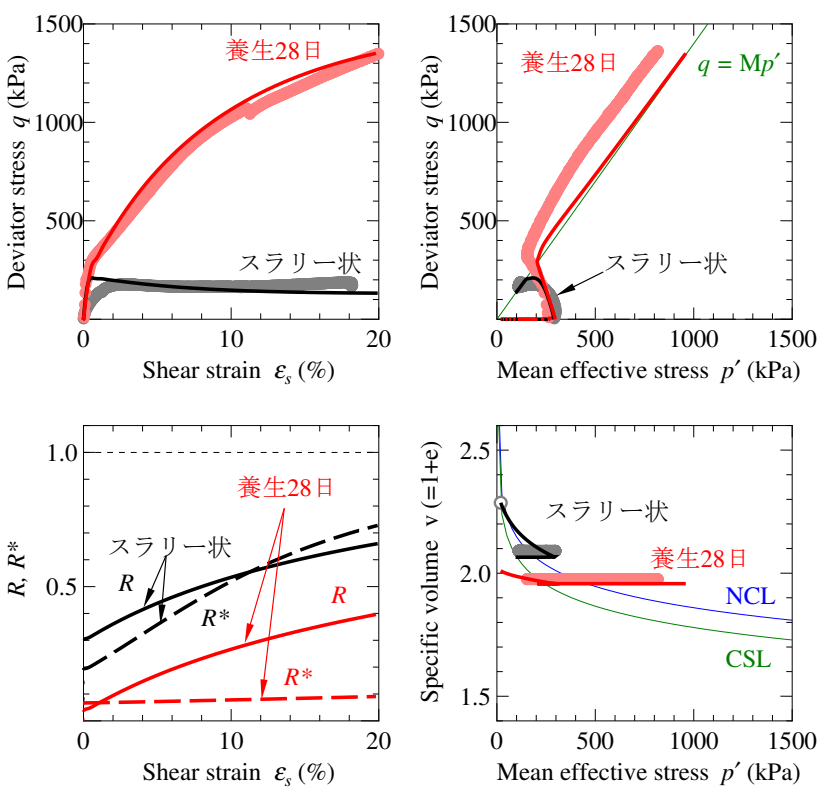

図-21 SYS Cam-clay modelによるキラ改良土（養生 28 日） の非排水三軸圧縮試験の再現

かわらず「強度」が大きいのは改良土が高位構造と大 きな過圧密比を獲得し，その構造がなかなか壊れない からである．構造とは自然堆積粘土の力学挙動で説明 するとわかりやすい。一次元圧密挙動であれば，練返 し土に比べ，構造を有する土は同じ比体積でも大きな 荷重を支える，またせん断挙動であれば，構造が大き い土ほど初期剛性が大きく，ピーク強度も大きい．ピー ク後に荷重が減少するのは，構造劣化によるものであ り，構造がなかなか壊れない土は，荷重低下を示さな い. 養生日数が増えるにつれて, 有効応力パスにおいて 
せん断後期の $q$ が $p^{\prime}$ とともに増加寸る硬化傾向は, 養 生に伴い過圧密比が大きくなるため, その解消に伴い 塑性膨張を伴う硬化挙動が卓越してくることによると 考察できる.

\section{5. 結論}

窝業副産物であるキラを地盤材料として有効利用す ることを目的とし，粉砕および石灰混合によりキラを 団粒化させ，突き固めによって締固めた試料を作製し， そのキラ改良土について力学試験を行った.さらに土 の骨格構造の働き（構造・過圧密・異方性）を記述す る SYS Cam-clay modelにより, 未改良キラとキラ改 良土の力学挙動を再現し, 骨格構造の概念に基づく解 釈をしたところ, 以下の結論を得た。

1）珪砂精製過程を経て排出されるキラは, 含水比が $33 \%$ 程度で, その一軸圧縮強度は $25 \mathrm{kPa}$ 程度であ る. 一方, 最大乾燥密度 $\rho_{d \max }=1.56 \mathrm{~g} / \mathrm{cm}^{3}$ で締 固めた試料の一軸圧縮強度は $110 \mathrm{kPa}$ であった。し かし締固められたキラは, 飽和化過程で短時間に 膨潤することが観察され，その膨潤はキラの密度 を小さくし, 強度が低下寸ることが推測され，こ のままでは地盤材料として用いることは困難であ ると考えられる。また, 三軸圧縮試験により得ら れたスラリー状キラおよび最適含水比で締固めた キラの非排水せん断挙動は, 砂のせん断挙動に類 似している. またSYS Cam-clay model による標 準圧密試験および三軸圧縮試験の力学挙動の再現 から, せん断に伴う過圧密解消と構造劣化の速度 が同程度であることがわかった。

2) 今回, 石灰混合率を $3 \%$ として実験を実施したが, キラ改良土については, 締固め前の仮置き日数が 2 日以上になると, 一軸圧縮強度は増加せず, 養生 しても石灰による固化作用は期待できない，一方 仮置きなしにおける改良土の一軸圧縮強度は, 28 日養生により $500 \mathrm{kPa}$ まで上昇し，0 日養生の約 5 倍となった。つまり現場においては, 破砕混合機 で石灰混合した材料は，長期間仮置きせずに，破 砕後 2 日以内には締固める必要がある.

3) キラ改良土は, 標準圧密試験結果から, 仮置きな しで養生することにより圧縮性が小さくなり， 28 日養生の圧縮量はかなり改善され, 0 日養生の 2 分 の 1 程度になる。また三軸圧縮試験結果からも, 養 生日数に応じて初期剛性は大きくなり, 最大軸差 応力も増加することがわかった. 仮置きしない改 良土の力学挙動を SYS Cam-clay model の構成式 応答によって再現した結果, 破砕・石灰混合・締
固めによって発展則パラメータが変化し, 構造劣 化速度, 過圧密解消速度が遅くなった。 また, 養 生の効果として, 初期構造が高位に, 初期過圧密 比が大きくなった．このことがキラ改良土の強度 増加の理由であり, 未改良キラよりも著しく良質 な土材料となった。

謝辞：増岡窐業原料 (株) よりキラの提供と, 表 -1 の 組成成分表 (化学分析表) の提示, その解説をして頂 き, 中部大学の杉井俊夫先生には保水性試験について 試験方法の教授だけでなく貴重なデータをご提供頂い た. また名古屋大学・浅岡顕先生には研究全般につい て貴重なご意見を頂いた。ここに付して感謝の意を表 する. なお本研究は, 科学研究費基盤研究 $(\mathrm{C})$ (課題番 号 18560483）の助成を得ている.

\section{付録 I SYS Cam-clay model の概要}

\section{（1）構造の定義}

三笠15)によると, 土の力学的性質は密度・含水量・骨 格構造という独立な 3 つの因子に分けられる. 飽和土 の場合, 練返し正規圧密土と自然堆積土の違いは骨格 構造の程度の差で表現される. 土の圧密挙動とせん断 挙動を同時に表現する弾塑性構成式としては Cam-clay model ${ }^{16)}$ が有名である. しかし, Cam-clay model は練 返し正規圧密粘土の実験結果に基づいており, その負 荷時の挙動しか記述することができない. 本研究で用 いるSYS Cam-clay model とは, Cam-clay model を土 台とし, 自然堆積土の力学挙動を記述するために骨格 構造として構造・過圧密・異方性の働きを考慮した弾塑 性構成式である.

図-I.1 は骨格構造の発達した自然堆積粘土の一次元 圧縮試験結果である. 図中に同じ土を完全に練り返した 試料の一次元圧縮線も示している.ここで「構造」を， 練返し試料に対して, 鉛直応力が同じならより大きな 比体積を取ることができる状態と定義する.つまり, 構 造の発達している土は練返し試料の圧縮線の外側に応 力状態を取ることができ, その「嵪張り」具合が構造 の程度を表す．しかし鉛直応力が増加して圧縮が進む と, その「嵩張り」具合は減少する. 寸なわち圧縮線 は次第に練返し試料の圧縮線に漸近し, 構造は喪失す る. 構造を有する土は負荷時の塑性変形によって喪失 し，練返し土に比べて大圧縮を示すことがわかる.

\section{（2）構造・過圧密・異方性の定量化表現とそれらの発 展則}

骨格構造の程度は, 練返し正規圧密土を基準に算定さ れる. 練返し正規圧密状態の土も異方性は存在するので, Sekiguchi and Ohta ${ }^{17)}$ による異方性を表す応力パラメー 


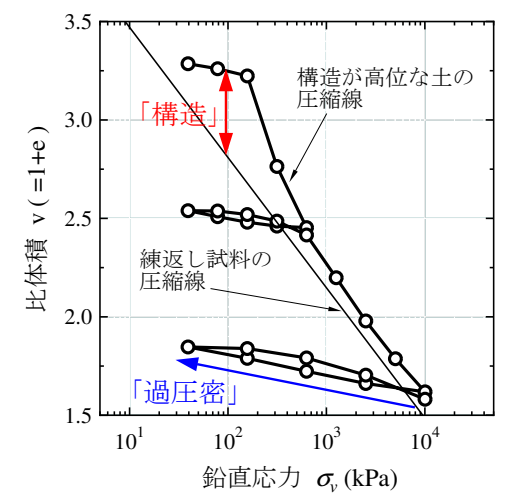

図-I.1 高位構造を有する粘土の一次元圧縮挙動

タ $\eta^{*}$ と，その発展を記述した Hashiguchi and Chen ${ }^{18)}$ による回転硬化概念を修正 Cam-clay model ${ }^{19}$ ) 導入 してその「基準」を確定する。構造の程度は Asaoka et al. ${ }^{3)}$,20) による上負荷面概念を, 過圧密の程度は Hashiguchi ${ }^{21)}$,22) による下負荷面概念を導入し定量化 する.すなわち，構造が発達した土は同じ間隙比でも Cam-clay model が表現する練返し土よりも大きな力を 支えることができるので, 構造の程度は Cam-clay 降伏 曲面（正規面）の外側に相似な上負荷面を導入し，相 似中心を原点 $p^{\prime}=q=0$ として大きさの相似率を $R^{*}$ $\left(0<R^{*} \leq 1\right)$ で定義する. 一方, 過圧密状態にある 土はこの上負荷面よりも内側に応力状態があるので, 過 圧密状態には上負荷面の内側に下負荷面を導入し, 相 似中心を原点 $p^{\prime}=q=0$ としてその大きさの相似率 を $R(0<R \leq 1)$ で定義する. ここに, $p^{\prime}$ は平均 有効応力, $q$ はせん断応力で, 有効応力 $\boldsymbol{T}^{\prime}$ (引張 : 正) を用いて，それぞれ， $p^{\prime}=-\operatorname{tr} \boldsymbol{T}^{\prime} / 3, q=\sqrt{3 / 2}\|\boldsymbol{S}\|$ $\left(\boldsymbol{S}=\boldsymbol{T}^{\prime}+p^{\prime} \boldsymbol{I}, \boldsymbol{I}\right.$ : 等方テンソル, \|\| : ノルムを示 す）で与えられる，相似率 $R^{*}$ は 0 に近いほど構造が高 位で, 塑性変形の進展に伴い, 構造が低位化して 1 に 近づく ( $R^{*}$ の発展則 $)$. 相似率 $R$ も0 に近いほどよ り過圧密な土で, 塑性変形の進展によって増加し, 正規 圧密状態へと近づくに従い 1 に近づく（ $R$ の発展則）. したがって, 塑性変形が進んで構造が低位化すると同 時に過圧密が解消（正規圧密状態一移行）し, 最終的に は Cam-clay 降伏曲面に一致すると仮定する。これら 3 つの負荷面の位置関係は, 軸対称条件では図-I.2 のよ うに描くことができる.

Cam-clay 降伏曲面と現有効応力がある下負荷面は, それぞれ式(I.1) と式(I.2)で表される.

$$
\begin{gathered}
\mathrm{MD} \ln \frac{\tilde{p}^{\prime}}{\tilde{p}_{0}^{\prime}}+\mathrm{MD} \ln \frac{\mathrm{M}^{2}+\eta^{* 2}}{\mathrm{M}^{2}}+\int_{0}^{t} J \operatorname{tr} \boldsymbol{D}^{p} d \tau \\
=f\left(\tilde{p}^{\prime}, \eta^{*}\right)+\int_{0}^{t} J \operatorname{tr} \boldsymbol{D}^{p} d \tau=0
\end{gathered}
$$

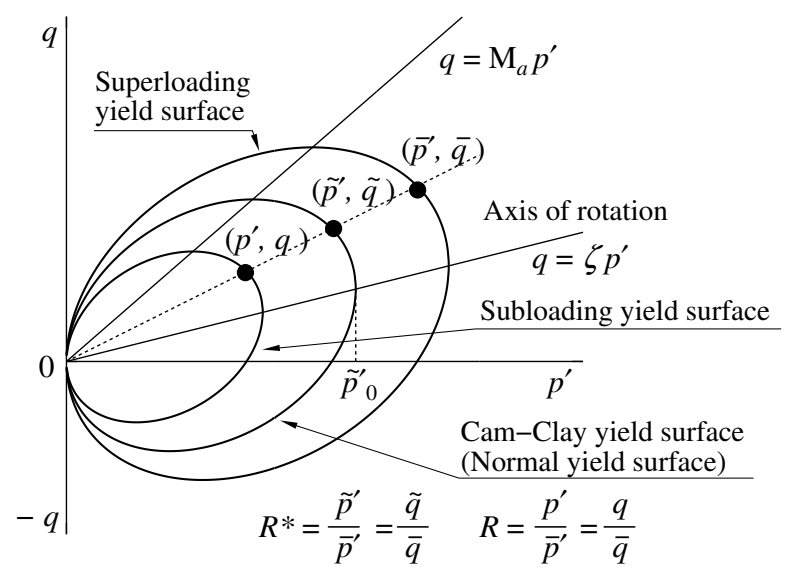

図-I.2 3 つの負荷面

$f\left(\tilde{p}^{\prime}, \eta^{*}\right)+\mathrm{MD} \ln R^{*}-\mathrm{MD} \ln R+\int_{0}^{t} J \operatorname{tr} \boldsymbol{D}^{p} d \tau=0$

ここに, $\mathrm{D}=(\tilde{\lambda}-\tilde{\kappa}) / \mathrm{M} /\left(1+\mathrm{e}_{0}\right)$ はダイレイタンシー 係数, $\mathrm{M}, \tilde{\lambda}, \tilde{\kappa}$ および $\mathrm{e}_{0}$ は限界状態定数, 圧縮指数, 膨潤指数および初期間隙比で, $J=(1+\mathrm{e}) /\left(1+\mathrm{e}_{0}\right) \quad(\mathrm{e}$ は時刻 $t=t$ での間隙比）である. $-\int_{0}^{t} J \operatorname{tr} \boldsymbol{D}^{p} d \tau$ は 塑性体積ひずみ（圧縮：正）に相当する.また，異方性 を表す $\eta^{*}$ は, 有効応力, 回転硬化変数 $\boldsymbol{\beta}$ などを用い て次式で表される.

$$
\eta^{*}=\sqrt{\frac{3}{2}}\|\hat{\boldsymbol{\eta}}\|, \quad \hat{\boldsymbol{\eta}}=\boldsymbol{\eta}-\boldsymbol{\beta}, \quad \boldsymbol{\eta}=\frac{\boldsymbol{S}}{p^{\prime}}
$$

本論文では, 塑性変形の進展に伴う, 構造 $\left(R^{*}\right)$, 過圧密 $(R)$, 異方性 $(\boldsymbol{\beta})$ の発展則を次式で与える. $R^{*}$ の発展則 :

$$
\begin{gathered}
\dot{R}^{*}=J U^{*}\left\{\left(1-c_{s}\right)\left(-\operatorname{tr} \boldsymbol{D}^{p}\right)+c_{s} \sqrt{\frac{2}{3}}\left\|\boldsymbol{D}_{s}^{p}\right\|\right\}, \\
U^{*}=\frac{a}{\mathrm{D}} R^{* b}\left(1-R^{*}\right)^{c}
\end{gathered}
$$

$R$ の発展則 :

$$
\dot{R}=J U\left\|\boldsymbol{D}^{p}\right\|, \quad U=-\frac{m}{\mathrm{D}} \ln R
$$

$\boldsymbol{\beta}$ の発展則 :

$$
\stackrel{\circ}{\boldsymbol{\beta}}=J \frac{b_{r}}{\mathrm{D}} \sqrt{\frac{2}{3}}\left\|\boldsymbol{D}_{s}^{p}\right\|\|\hat{\boldsymbol{\eta}}\|\left(m_{b} \frac{\hat{\boldsymbol{\eta}}}{\|\hat{\boldsymbol{\eta}}\|}-\boldsymbol{\beta}\right)
$$

ここに， $\boldsymbol{D}^{p}$ は塑性ストレッチングでストレッチング $\boldsymbol{D}$ を和分解したときの塑性成分, $\operatorname{tr} D^{p}, D_{s}^{p}$ はそれぞれ塑 性ストレッチングの体積成分と偏差成分を表す。また, 式(I.6) 中の $\stackrel{\beta}{\boldsymbol{\beta}}$ は, $\boldsymbol{\beta}$ の Diense 速度である. 式 (I.4) 式 (I.6) の発展則パラメータ群 $a, b, c, c_{s}, m, b_{r}, m_{b}$ は 全て定数で，それぞれの「役割」から， $a, b, c, c_{s}$ を構 造低位化指数, $m$ を正規圧密土化指数, $b_{r}$ を回転硬化

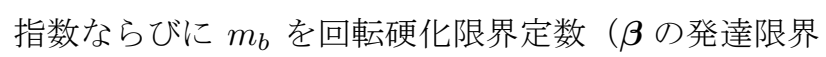
を表す）と呼ぶ. 

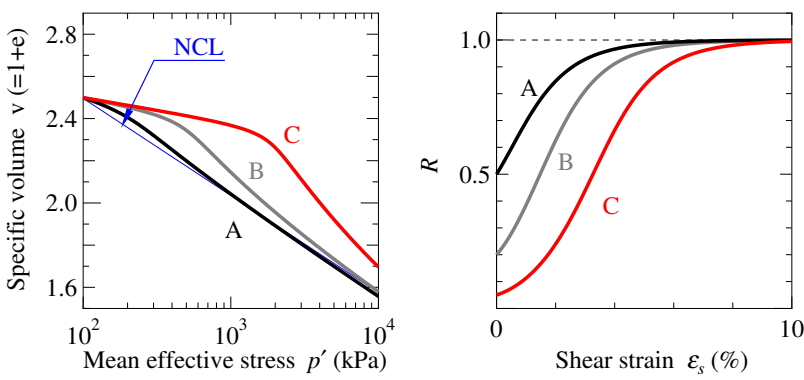

図-I.3 初期状態の異なる粘土の一次元圧縮挙動

図-I.3 は，初期過圧密比 $1 / R_{0}$ と初期構造の程度 $1 / R_{0}^{*}$ が異なる土 $\mathrm{A}, \mathrm{B}, \mathrm{C}$ の一次元圧縮挙動を SYS Camclay model によって計算した結果である. 3 種類の土 は，弾塑性パラメータ，発展則パラメータは全て同じ で, 初期比体積, 初期応力状態も同じ值に設定した. 図 には塑性変形の進展に伴う $R$ の変化 $\left(R \sim \varepsilon_{s}\right.$ 図 $)$ も示 している. 図より, 弾塑性パラメータ, 発展則パラメー タが同じでも初期過圧密比と初期構造の程度が違うと, 土の力学挙動は異なることが分かる.

\section{(3) 関連流れ則と構成式}

現有効応力は常に下負荷面 式 (I.2) 上にあるので，下 負荷面について, 関連流れ則, Prager の適応条件など, 通常の弾塑性諸法則を適用すると, 負荷時の塑性乗数 は次式で表される.

$$
\begin{aligned}
& \text { 関連流れ則 : } \boldsymbol{D}^{p}=\lambda \frac{\partial f}{\partial \boldsymbol{T}^{\prime}}, \\
& \lambda=\frac{\frac{\partial f}{\partial \boldsymbol{T}^{\prime}} \cdot \stackrel{\circ}{\boldsymbol{T}}^{\prime}}{J \frac{\mathrm{MD}}{p^{\prime}\left(\mathrm{M}^{2}+\eta^{* 2}\right)}\left(\mathrm{M}_{s}{ }^{2}-\eta^{2}\right)}(>0)
\end{aligned}
$$

ここに,

$$
\begin{aligned}
& \mathrm{M}_{s}^{2}=\mathrm{M}_{a}^{2}+b_{r} \frac{4 \mathrm{M} \eta^{* 2}}{\mathrm{M}^{2}+\eta^{* 2}}\left(m_{b} \eta^{*}-\sqrt{\frac{3}{2}} \hat{\boldsymbol{\eta}} \cdot \boldsymbol{\beta}\right) \\
& -\mathrm{MD}\left(\frac{U^{*}}{R^{*}} 2 \eta^{*}-\frac{U}{R} \sqrt{6 \eta^{* 2}+\frac{1}{3}\left(\mathrm{M}_{a}^{2}-\eta^{2}\right)^{2}}\right)
\end{aligned}
$$

で, $\mathrm{M}_{a}^{2}=\mathrm{M}^{2}+\zeta^{2}, \zeta=\sqrt{3 / 2}\|\boldsymbol{\beta}\|$ である.

一方, 有効応力変化は弾性変形によって生じるとし

て, 非線形 Hooke 則を仮定すると, 構成式は次式で表 される。

$$
\stackrel{\circ}{\boldsymbol{T}}^{\prime}=\boldsymbol{E} \boldsymbol{D}-\Lambda \boldsymbol{E} \frac{\partial f}{\partial \boldsymbol{T}^{\prime}}
$$

ここに, $\boldsymbol{E}$ は弾性係数テンソル， $\boldsymbol{T}^{\prime}$ は $\boldsymbol{T}^{\prime}$ の Dienes 速度， $\Lambda$ は塑性乗数 $\lambda$ のストレッチング $\boldsymbol{D}$ による表 記である。

\section{参考文献}

1) 愛知県瀬戸窯業技術センター, 愛知県珪砂鉱業協同組合 : 微粒珪砂等の実態調查報告, pp.1-13, 1993.

2）二宮康治，赤神元英，尾山利彦，宮本光則：回転式破砕 混合工法を用いた事前混合処理工法の実施例，第 1 回土 木建設技術シンポジウム, 土木学会, pp.225-232, 2002.

3) Asaoka, A., Nakano, M. and Noda, T. : Superloading yield surface concept for highly structured soil behavior, Soils and Foundations, No.40, Vol.2, pp.99-110, 2000.

4) Asaoka, A., Noda, T., Yamada, E., Kaneda, K. and Nakano, M. : An elasto-plastic description of two distinct volume change mechanisms of soils, Soils and Foundations, Vol.42, No.5, pp.47-57, 2002.

5）セメント改良土の物性と試験方法に関する研究委員会 : セメント及びセメント系固化材を用いた固化処理土の調 查・設計・施工方法と物性評価に関するシンポジウム発 表論文集, 地盤工学会, 2005.

6) Kasama, K., Ochiai, H. and Yasufuku, N. : On the stress-strain behavior of lightly cemented clay based on an extented critical state consept, Soils and Foundations, Vol.40, No.5, pp.37-47, 2000.

7) Lee, K., Chan, D. and Lam, K. : Constitutive model for cement treated clay in a critical state frame work, Soils and Foundations, Vol.44, No.3, pp.69-77, 2004.

8) 呉智深, 安原一哉, 牛赫東, 殷峻 : 過圧密土としての軽 量地盤材料の構成則に関寸る研究—混合軽量土の歪み硬 化・軟化モデルについて, 過圧密土および過圧密地盤の 力学に関するシンポジウム発表論文集, pp.1-6, 2000.

9) 岡二三生, 今井政人, 中島伸一郎 : セメント改良砂質土 の強度変形特性とモデル化, 第 38 回地盤工学研究発表 会論文集，pp.756-766，2003.

10） セメント協会：セメント系固化材による地盤改良マニュ アル第 3 版，技報堂出版，pp.26-32, 2003.

11）日本道路公団試験研究所試験研究推進委員会材料施工研 究会：試験研究所技術資料 127 号，材料施工資料 (第 7 号)，土質安定材 (固化材), pp.8-11, 1997.

12）杉井俊夫，伊藤 隆：水分特性曲線推定のための保水性 試験について, 平成 19 年度土木学会中部支部研究発表会 講演概要集, pp.229-230, 2008.

13) Asaoka, A. : Consolidation of Clay and Compaction of Sand -An elasto-plastic description-, Keynote lecture, Proc. 12th Asian Regional Conf. on Soil Mechanics and Geotechnical Engineering, Singapore, Vol.2, pp.1157-1195, 2003.

14）田代むつみ, 野田利弘, 中野正樹 : 土の骨格構造の働き に着目した「擬似過圧密効果」の一考察, 応用力学論文 集, 土木学会, Vol.7, pp.589-596, 2004.

15）三笠正人：土の工学的性質の分類表とその意義, 土と基 礎, Vol.12, No.4, pp.17-24, 1964.

16) Schofield, A. N. and Wroth, C. P. : Critical State Soil Mechanics, McGraw-Hill, 1968.

17) Sekiguchi, H. and Ohta, H. : Induced anisotropy and time dependency in clays, Proc. 9th Int. Conf. Soil Mech. Found. Eng., Tokyo, Japan, pp.229-238, 1977.

18) Hashiguchi, K. and Chen, Z. P. : Elastoplastic constitutive equations of soils with the subloading surface and the rotational hardening, Int. J. Numer. Anal. Meth. Geomech., Vol.22, pp.197-227, 1998.

19) Roscoe, K. H., and Burland, J. B. : On the generalized stress-strain behavior of 'wet' clay, in J. Heyman and F. A. Leckie (eds.), Engineering Plasticity (Cambridge: Cambridge University Press), pp.535609, 1968.

20) Asaoka, A., Nakano, M. and Noda, T. : Superload- 
ing yield surface concept for the saturated structured soils, Proc. 4th European Conf. on Numerical Methods in Geotechnical Engineering, Udine, Italy, pp.233242, 1998.

21) Hashiguchi, K. and Ueno, M. : Elasto-plastic constitutive laws of granular materials, Proc. 9th Int. Conf. Soil Mech. Found. Eng., Tokyo, Japan, pp.7382, 1977.
22) Hashiguchi, K. : Subloading surface model in unconventional plasticity, Int. J. of Solids and Structures, Vol. 25, pp.917-945, 1989.

(2008.7.3 受付)

\title{
MECHANICAL PROPERTIES OF A CERAMIC INDUSTRIAL BY-PRODUCT "KIRA" IMPROVED BY CRUSHING, LIME-MIXING AND COMPACTING PROCESS
}

\author{
Masaki NAKANO and Eiji YAMADA
}

\begin{abstract}
In order to use a ceramic industrial by-product "Kira" as a geomaterial, KIRA is improved by crushing, lime-mixing and compaction and its mechanical properties are investigated through laboratory tests and numerical simulations. The new findings as follows; 1) The unimproved soil is the soil in which the loss of overconsolidation proceeds as fast as the decay in structure with plastic deformation. 2) The 28-day strength is about 5 times as larger as the 0-day strength and the compressibility with 28 days curing is half of the one with 0 day. 3) A mixing "Kira" with lime makes speed of decay of soil structure and loss of overconsolidation decrease, and a curing makes initial structure high and initial overconsolidation heavy.
\end{abstract}

